\title{
SUBCONJUNCTIVAL FRAGMENTATION OF A PREVIOUSLY EFFICIENT XEN GEL STENT IMPLANTATION AND SUCCESSFUL BLEB FORMATION: A CASE REPORT
}

\begin{abstract}
Katia Novak-Lauš, Lana Knežević, Goran Marić, Mia Zorić Geber and Zoran Vatavuk
Department of Ophthalmology, Sestre milosrdnice University Hospital Centre, Zagreb, Croatia

SUMMARY - The XEN gel stent is one of the available minimally invasive glaucoma surgery devices, a new generation implant, which is designed to reduce intraocular pressure in patients with primary open angle glaucoma if past medical treatments have failed. This report presents a case of subconjunctival fragmentation of the XEN gel stent after a three-month follow-up of successful XEN gel implantation. A 70-year-old male patient was treated for primary open angle glaucoma. He underwent successful phacoemulsification and intraocular lens implantation two years before. Due to medical therapy failure in controlling glaucoma, $\mathrm{XEN}$ gel stent implantation was suggested to the patient. The implant was successfully placed in both eyes, and extended bleb and drainage aqueous humor from the anterior chamber to the subconjunctival space was obtained. Three months after the surgery, at a regular follow-up visit, three fragments of the subconjunctival part of the XEN gel implant were found in his left eye. Neither serious complications nor intraocular pressure increase were detected. A new potential complication of the XEN gel implant is described.
\end{abstract}

Key words: Intraocular pressure; Glaucoma, open-angle; Lens implantation, intraocular; Stents; Minimally invasive surgical procedures; Filtering surgery

\section{Introduction}

A novel technique of creating an alternative route through an $a b$ interno approach via implantation of a collagen implant XEN (Allergan, Irvine, CA, USA) has been described in an attempt to overcome different complications that are seen in glaucoma filtration surgery $^{1,2}$. The XEN implant has been approved by the European Medicines Agency and the U.S. Food and Drug Administration for surgical treatment of glaucoma. The XEN gel stent is a 6-mm hydrophilic tube with a 45- $\mu \mathrm{m}$ lumen size, composed of a porcine collagen-derived gelatin crosslinked with glutaraldehyde. This gelatin stent provides ab interno approach and

Correspondence to: Prof. Katia Novak-Lauš, MD, PhD, Department of Ophthalmology, Sestre milosrdnice University Hospital Centre, Vinogradska c. 29, HR-10000 Zagreb, Croatia

E-mail:katia@midij-com.hr

Received May 8, 2019, accepted June 18, 2019 bypasses the natural drainage pathways, which often become obstructed and cause elevated intraocular pressure (IOP). The ideal stent placement should be $2.0 \mathrm{~mm}$ of exposed implant in the subconjunctival space, $1.0 \mathrm{~mm}$ in the anterior chamber and $3.0 \mathrm{~mm}$ tunneled through the sclera. However, some cases of stent exposure have been described in the literature ${ }^{3}$, as well as dislocation of XEN gel into the anterior chamber $^{4}$, XEN gel internal ostium occlusion ${ }^{5}$, suprachoroidal bleeding after XEN gel implantation ${ }^{6}$, and postoperative hypotony associated with a shallow anterior chamber and choroidal effusions after surgery ${ }^{7}$. As with all new devices, there is a lack of experience and knowledge about its long-term results in terms of efficacy, technique and complications ${ }^{8}$.

\section{Case Report}

This report presents a case of subconjunctival fragmentation of the XEN gel implant three months after 

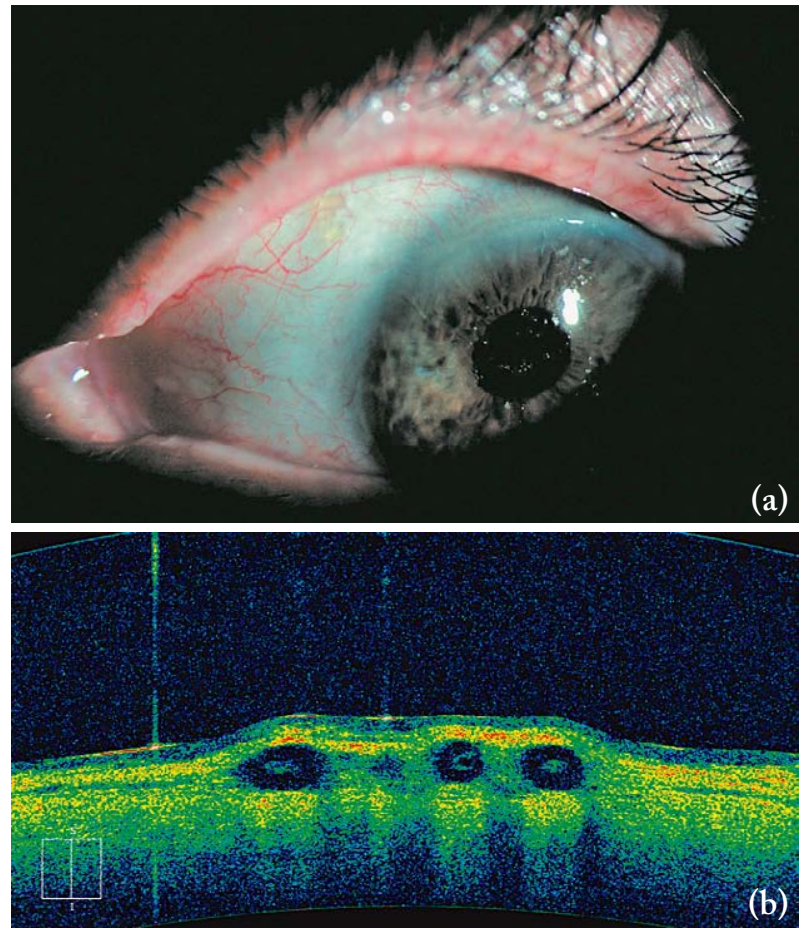

Fig. 1. Subconjunctival fragments of the XEN gel stent: (a) slit lamp photograph; (b) anterior segment optical coherence tomography.

the surgery. Consent for publication of this case report was obtained from the patient. A 70-year-old male was treated and followed-up for primary open angle glaucoma in the Glaucoma Unit, Department of Ophthalmology, Sestre milosrdnice University Hospital Centre, Zagreb, Croatia. The patient underwent successful phacoemulsification and intraocular lens implantation two years before. Before surgery, the IOP was $26 \mathrm{~mm} \mathrm{Hg}$ in the right eye and $24 \mathrm{~mm} \mathrm{Hg}$ in the left eye despite maximum tolerated topical treatment with three IOP lowering medications (bimatoprost/ timolol fixed combination once in the evening and dorzolamide twice a day). Since IOP was poorly controlled, XEN implantation was offered to the patient for both eyes, and the patient consented to the procedure offered. Surgical steps for XEN implantation in both eyes included the following: $0.2 \mathrm{mg} / \mathrm{mL}$ of mitomycin $\mathrm{C}$ injected subconjunctivally in the area of planned XEN implantation, marking the conjunctiva $3 \mathrm{~mm}$ from the limbus superonasally. The anterior chamber was filled with Healon GV (Abbot Medical Optics, Inc., Santa Ana, CA, USA) and inferotemporal 1.8-mm clear corneal incision was created through

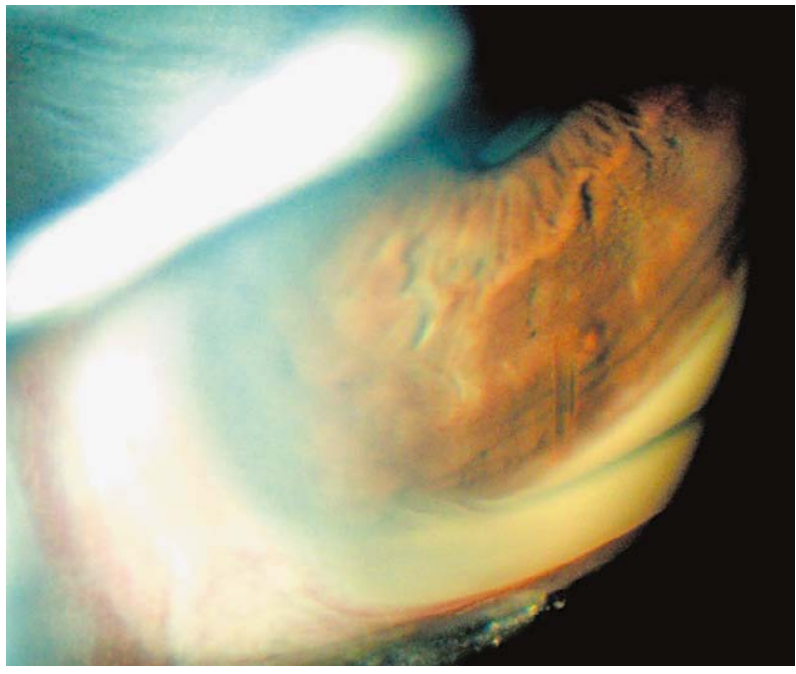

Fig. 2. Gonioscopic view of the anterior chamber part of the XEN gel stent.

which the preloaded inserter needle (double beveled 27-gauge) was directed across the anterior chamber in the opposite side to penetrate the angle under gonioscopic view. Once the needle was visible in the subconjunctival space, it was rotated toward 12 oclock and the stent was gently injected into the subconjunctival space. Healon GV was irrigated out of the anterior chamber at the end of surgical procedure. Intraoperative mild intracameral hemorrhage occurred but it was promptly resolved with irrigation-aspiration procedure. Due to overlong intrachamber part of the implant, the blunt tweezer was used to relocate the implant by scleral approach. The implant immediately began shunting fluid from the anterior chamber to the subconjunctival space with an initial extended bleb due to the gentle diffuse dispersion of aqueous humor into the non-dissected conjunctiva.

Postoperative treatment included a combination of dexamethasone and tobramycin administered 4 times daily for 15 days and then slowly reduced over the next 2 weeks.

The surgery was successful in both eyes. Slit lamp examination confirmed proper positioning of the XEN implant and successful bleb formation. IOP was 14 $\mathrm{mm} \mathrm{Hg}$ in the right eye and $15 \mathrm{~mm} \mathrm{Hg}$ in the left eye (with no IOP lowering medications) one and two months after the surgery.

Three months after the surgery, at the regular follow-up visit, an uncommon adverse event was found. We noticed three fragments of the subconjunctival 
part of the XEN gel in the patient's left eye, as shown by slit-lamp and anterior segment optical coherence tomography (Fig. 1a and b). The IOP was $14 \mathrm{~mm} \mathrm{Hg}$ despite the fact that there was no bleb formation in the area of previous XEN implantation. Gonioscopic view showed the intracameral part of the implant to be correctly located inside the Schlemm's canal (Fig. 2).

\section{Discussion and Conclusions}

Our report suggests that subconjunctival fragmentation of the XEN gel implant can occur after successful placement and functional bleb formation. The implant is a hydrophilic, non-inflammatory subconjunctival gelatin stent. The gelatin stent swells and becomes soft when hydrated, which helps maintain its intended position as it adapts to the shape of the surrounding tissues to create permanent channel from the anterior chamber to the subconjunctival space ${ }^{9}$. This occurs within 2 minutes after implantation. Relocating the implant by scleral approach in case of short subconjunctival part (less than $2 \mathrm{~mm}$ ) and long intracameral part (more than $1 \mathrm{~mm}$ ) is an ordinary procedure during surgery. The patient denied rubbing the eye or any other possible incident during those three months. For this reason, relocating the implant by scleral approach with blunt tweezers should not lead to the risk of stent fragmentation, especially because of its gelatinous properties.

However, this case report presents an uncommon adverse event detected at regular follow-up visit. In this case, after fragmentation of the XEN gel, the implant does not utilize subconjunctival filtration for aqueous outflow. Subconjunctival filtration creates a non-physiologic route for aqueous outflow, which is the basis of traditional trabeculectomy and aqueous shunt glaucoma surgery ${ }^{5,6}$.

In conclusion, our report suggests a new potential complication of the XEN gel stent implantation. The mechanism of its occurrence remains unclear. At this moment, we are unaware of any report on subconjunctival XEN gel fragmentation available in the literature. This could imply clinical significance of this case report as the first report on the subconjunctival XEN gel fragmentation at three-month follow-up of successful and effective XEN gel implantation.

\section{References}

1. Lewis RA. Ab interno approach to the subconjunctival space using a collagen glaucoma stent. J Cataract Refract Surg. 2014 Aug;40(8):1301-6. doi: 10.1016/j.jcrs2014.01.032.

2. Watson PG, Jakeman C, Ozturk M, Barnett MF, Barnett F, Khaw KT. The complications of trabeculectomy (a 20-year follow-up). Eye. 1990;4:425-38. doi: 10.1038/eye.1990.54.

3. Fea A, Cannizzo PM, Consolandi G, Lavia CA, Pignata G, Grignolo FM. Managing drawbacks in unconventional successful glaucoma surgery. A case report of stent exposure. Case Rep Ophthalmol Med. 2015;2015:847439. doi: 10.1155/ 2015/847439.

4. Dervenis N, Mikropoulou AM, Dervenis P, Lewis A. Dislocation of a previously successful XEN glaucoma implant into anterior chamber: a case report. BMC Ophthalmology. 2017; 17:148. doi: 10.1186/s12886-017-0540-1.

5. Ferreira NP, Pinto LA, Naves CM. XEN gel stent internal ostium occlusion: ab-interno revision. J Glaucoma. 2017;26: 150-2. doi: 10.1097/IJG.0000000000000625.

6. Prokosch-Willing V, Vossmerbaeumer U, Hoffmann E, Pfeiffer N. Suprachoroidal bleeding after XEN gel implantation. J Glaucoma. 2017;26(12):e261-e263. doi: 10.1097/IJG000000 0000000795.

7. Bruynseels A, Sii F, Masood I, Shah P. Severe intraocular pressure elevation after intracameral Healon 5 viscoelastic support for postoperative hypotony after XEN gel stent insertion. J Glaucoma. 2018 Apr;27(4):e75-e76. doi: 10.1097/IJG000000 0000000883.

8. Richter GM, Coleman AL. Minimally invasive glaucoma surgery: current status and future prospects. Clin Ophthalmol. 2016 Jan 28;10:189-206. doi: 10.2147/OPTH.S80490.

9. Grover DS, Flynn WJ, Bashford KP, Lewis RA, Duh YJ, Nangia RS, et al. Performance and safety of a new ab interno gelatin stent in refractory glaucoma at 12 months. Am J Ophthalmol. 2017 Nov;183:25-36. doi: 10.1016/j.ajo.2017.07.023. 


\title{
Sažetak \\ SUBKONJUNKTIVNA FRAGMENTACIJA XEN GEL STENTA NAKON PRETHODNO USPJEŠNE IMPLANTACIJE I POSLJEDIČNOG FORMIRANJA FILTRACIJSKOG JASTUČIĆA: PRIKAZ SLUČAJA
}

\author{
K. Novak-Laǔ́, L. Knežević, G. Marić, M. Zorić-Geber i Z. Vatavuk
}

XEN gel stent je implantat nove generacije koji se rabi u minimalno invazivnoj kirurgiji glaukoma, namijenjen za snižavanje intraokularnog tlaka u bolesnika s glaukomom primarno otvorenog kuta kada prethodno liječenje nije dovelo do željenog rezultata. Prikazan je slučaj bolesnika kod kojega je nakon tri mjeseca praćenja uspješno implantiranog XEN gel stenta došlo do njegove subkonjunktivne fragmentacije. Muškarac u dobi od 70 godina liječen je zbog glaukoma otvorenog kuta. Dvije godine ranije imao je uspješnu operaciju katarakte s ugradnjom intraokularne leće. Zbog neuspješne kontrole glaukoma medikamentnom terapijom bolesniku je predložena implantacija XEN gel stenta. Implantat je uspješno implantiran u oba oka te je omogućen protok očne vodice iz prednje očne sobice u subkonjunktivni prostor uz formiranje filtracijskog jastučića. Tri mjeseca nakon operacije lijevoga oka, na redovnoj kontroli vizualizirana su tri fragmenta subkonjunktivnog dijela XEN gel stenta, bez da je prethodno bilo ozbiljnijih komplikacija ili porasta intraokularnoga tlaka. Opisana je nova moguća komplikacija XEN gela implantata.

Ključne riječi: Intraokularni tlak; Glaukom otvorenog kuta; Leće, intraokularne, ugradnja; Stentovi; Minimalno invazivni kirurški postupci; Filtracijska kirurgija 